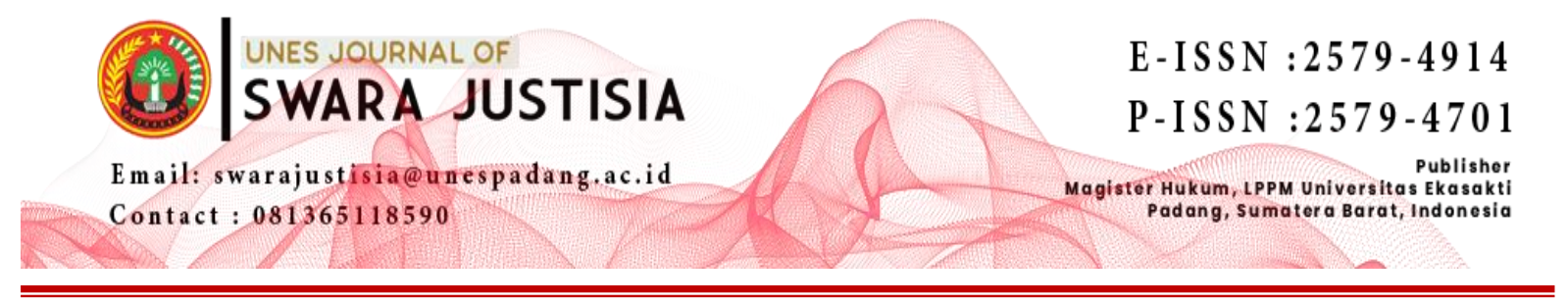

\title{
PENYIDIKAN TINDAK PIDANA PEMILU PADA MASA KAMPANYE PEMILU TAHUN 2019 OLEH PENYIDIK SATRESKRIM POLRES SOLOK KOTA
}

\author{
Rizky Mahesa Febriandi \\ Program Magister Ilmu Hukum, Universitas Ekasakti, Padang, Indonesia \\ Email: rizkyfebryand@gmail.com
}

\begin{abstract}
Investigation of Election Crime During the 2019 Election Campaign Period By Investigators of the Solok Kota Police Satreskrim begins with the activities of Investigators accompanying Bawaslu to receive findings / reports of alleged election crimes, then no later than 14 (fourteen) days the investigator will assist Bawaslu in conducting clarifications and studies, after it is concluded that the finding / report is an election criminal act, then the report is forwarded to the Police by making a Police Report, furthermore that no later than 14 (fourteen) days the Investigator will carry out the investigation and no later than 14 (fourteen) days the case files resulting from the investigation have been submitted to Penunutut. General. Within a maximum period of 6 (six) days from the date of receipt of case files, the investigator delegates the responsibility of the case to the public prosecutor without or after going through the process of returning the case files. The obstacles faced by Solok Kota Police's Satreskrim Investigators in Investigating Election Crime during the 2019 Election Campaign Period include, external constraints, namely a) the handling of reports on election crimes cannot be followed up if one of the Gakkumdu elements (Bawaslu, investigators, prosecutors) does not agree to follow up on their own normative reasons; $(b)$ the limitation of the time period for handling election crimes is not followed by the legal consequences that will occur if the handling of the crime committed exceeds the predetermined time period; (c) time limitation for handling election crimes greatly hinders Election Crime Investigators from working optimally in gathering evidence. internal constraints, namely a) limited facilities and infrastructure required for investigation and investigation activities; $b$ ) Election Crime Investigators are still weak in their mastery of laws or regulations relating to the 2019 Election.
\end{abstract}

Keywords: Investigation, Election Crime, Campaign Period

\begin{abstract}
ABSTRAK
Penyidikan Tindak Pidana Pemilu Pada Masa Kampanye Pemilu 2019 Oleh Penyidik Satreskrim Polres Solok Kota diawali dengan kegiatan Penyidik mendampingi Bawaslu untuk menerima temuan/laporan dugaan tindak pidana Pemilu, selanjutnya paling lambat 14 (empat belas) hari penyidik akan mendampingi Bawaslu dalam melakukan klarifikasi dan penelitian, setelah disimpulkan bahwa temuan/laporan tersebut merupakan tindak pidana pemilu, maka laporan tersebut diteruskan kepada Kepolisian dengan membuat Laporan Polisi, selanjutnya paling lambat 14 (empat belas) hari Penyidik akan melaksanakannya. penyidikan dan paling lambat 14 (empat belas) hari berkas perkara hasil penyidikan tersebut telah diserahkan kepada Penuntut Umum. Umum. Dalam jangka waktu paling lama 6 (enam) hari terhitung
\end{abstract}


sejak tanggal penerimaan berkas perkara, penyidik melimpahkan tanggung jawab perkara tersebut kepada penuntut umum tanpa atau setelah melalui proses pengembalian berkas perkara. Kendala yang dihadapi Penyidik Satreskrim Polres Solok Kota dalam Penyidikan Tindak Pidana Pemilu pada Masa Kampanye Pemilu 2019 antara lain, kendala eksternal yaitu a) penanganan laporan tindak pidana pemilu tidak dapat ditindaklanjuti jika salah satu unsur Gakkumdu (Bawaslu, penyidik, jaksa) tidak setuju untuk menindaklanjuti alasan normatif mereka sendiri; (b) pembatasan jangka waktu penanganan tindak pidana pemilu tidak diikuti dengan akibat hukum yang akan terjadi apabila penanganan tindak pidana yang dilakukan melebihi jangka waktu yang telah ditentukan; (c) keterbatasan waktu penanganan tindak pidana Pemilu sangat menghambat Penyidik untuk bekerja maksimal dalam mengumpulkan bukti. kendala internal yaitu a) terbatasnya sarana dan prasarana yang diperlukan untuk kegiatan penyidikan dan penyidikan; b) Penyidik Tindak Pidana Pemilu masih lemah dalam penguasaan peraturan perundang-undangan terkait Pemilu 2019.

Kata Kunci: Penyidikan, Tindak Pidana Pemilu, Masa Kampanye

\section{PENDAHULUAN}

Pelaksanaan pemilu tidak terlepas dari kegiatan retorika, publik relasi, komunikasi massa, lobi politik dan lain-lain kegiatannya. Meskipun agitasi dan propaganda di Negara demokrasi sangat dikecam, namun dalam kampanye pemilihan umum, teknik agitasi dan teknik propaganda banyak juga dipakai oleh para kandidat atau politikus selaku komunikator politik. Dalam pelaksanaan pemilu di lapangan banyak sekali ditemukan kecurangan yang dilakukan oleh para calon, seperti melakukan politik uang, intimidasi, kampanye diluar jadwal, kampanye negatif, manipulasi data, dan lain-lain.

Undang-Undang (UU) tentang Pemilihan Umum resmi ditandatangani oleh Presiden RI Ir. Joko Widodo pada 15 Agutus 2017 dan telah diundangkan pada 16 Agustus 2017, UU No. 7 Tahun 2017 tentang Pemilihan Umum ini menjadi dasar hukum penyelenggaraan Pemilu DPR, DPD, DPRD dan Pemilihan Presiden dan Wakil Presiden (Pilpres) tahun 2019 yang diselenggarakan secara serentak. Menurut Pasal 1 angka 1 UU No. 7 Tahun 2017 tentang Pemilihan Umum disebutkan bahwa Pemilihan Umum yang selanjutnya disebut Pemilu adalah sarana kedaulatan rakyat untuk memilih Anggota Dewan Perwakilan Rakyat, Anggota Dewan Perwakilan Daerah, Presiden dan Wakil Presiden, dan untuk memilih anggota Dewan Perwakilan Rakyat Daerah, yang dilaksanakan secara langsung, umum, bebas, rahasia, jujur, dan adil dalam Negara Kesatuan Republik Indonesia berdasarkan Pancasila dan Undang-Undang Dasar Negara Republik Indonesia Tahun 1945.

Mengingat diundangkannya UU No. 7 Tahun 2017 tentang Pemilihan Umum tersebut, juga mengatur tentang tindak pidana pemilu (Pasal 476, dan Pasal 477, dan Pasal 480), maka Peraturan Badan Pengawas Pemilihan Umum Nomor 9 Tahun 2018 tentang Sentra Penegakan Hukum Terpadu sudah tidak sesuai dengan perkembangan dan kebutuhan hukum sehingga perlu diganti, dan menetapkan Peraturan Badan Pengawas Pemilihan Umum tentang Sentra Penegakan Hukum Terpadu, yakni Peraturan Badan Pengawas Pemilu Republik Indonesia Nomor 31 Tahun 2018 tentang Sentra Penegakan Hukum Terpadu.

Menurut Djoko Prakoso "setiap orang, badan hukum atau organisasi dengan sengaja melanggar hukum, mengacaukan menghalanghalangi atau mengganggu jalannya Pemilu yang diselenggarakan menurut undang-undang”, pada UU No. 7 Tahun 2017 tentang Pemilihan Umum memperlihatkan keseriusan pemerintah dalam memberantas pidana Pemilu melalui 
pembentukkan Sentra Penegakan Hukum Terpadu (Gakkumdu). ${ }^{1}$ Mengingat UU No. 7 Tahun 2017 telah mengatur secara khusus mengenai jenis dan beratnya ancaman serta bagaimana penanganan tindak pidana Pemilu 2019 harus dilakukan, sedari awal mestinya tidak ada kekhawatiran akan efektivitas penegakan hukum terhadap pelaku tindak pidana dalam Pemilu 2019. Namun, melihat sedikitnya jumlah laporan tindak pidana pemilu yang berlanjut ke tingkat penyidikan, penuntutan, dan pemeriksaan di sidang pengadila sampai keluarnya putusan yan berkekuatan hukum tetap (inkrach van gewisjde), membuktikan penanganan tindak pidana pemilu dalam Pemilu 2019 belum berjalan efektif sekalipun sudah tersedia saluran koordinasi antar penegak hukum dalam wadah Sentra Gakkumdu.

Penegakan hukum di dalam sistem peradilan pidana bertujuan untuk menanggulagi setiap kejahatan. Bahwa yang dimaksud sistem peradilan pidana ialah suatu sistem berprosesnya suatu peradilan pidana, dimana masing-masing komponen fungsi yang terdiri dari kepolisian sebagai penyidik, kejaksaan sebagai penuntut umum, pengadilan sebagai pihak yang mengadili dan lembaga pemasyarakatan yang berfungsi untuk memasyarakatkan kembali para terhukum, yang bekerja secara bersama sama, terpadu dalam usaha untuk mencapai tujuan bersama yaitu untuk menanggulangi kejahatan. ${ }^{2}$

Berdasarkan Peraturan Komisi Pemilihan Umum (PKPU) Nomor 32 Tahun 2018 tentang Perubahan Kedua Atas Peraturan KPU Nomor 7 Tahun 2017 tentang Tahapan, Program, dan Jadwal Penyelenggaraan Pemilihan Umum Tahun 2019, Komisi Pemilihan Umum RI menetapkan tahapan Pemilu 2019 dengan masa kampanye dengan masa yang relatif lama, yakni tanggal 23 September 2018-13 April 2019, merupakan jadwal kampanye calon anggota DPR, DPD, dan DPRD, serta pasangan calon Presiden dan Wakil Presiden.

Berdasarkan Data Penyelesaian Perkara Tindak Pidana Pemilu Tahun 2019 dari Urmintu Satreskrim Polres Solok Kota, selama tahapan pemilu 2019 Satreskrim Polres Solok Kota telah menangani 9 (sembilan) perkara tindak pidana pemilu yang sudah berkeputusan hukum tetap (inkracht), Dari 9 (sembilan) perkara tindak pidana pemilu yang telah ditangani oleh Satreskrim Polres Solok Kota tersebut, 3 (tiga) perkara merupakan tindak pidana pemilu yang terjadi pada masa kampanye, diantaranya adalah :

1. Laporan Polisi Nomor : LP/236/B/XI/2018/Polres Solok Kota tgl 07 November 2018, tentang tindak pidana pemilu kampanye yang dilarang berupa menghina pelaksana kampanye pemilu lain sebagaimana dimaksud dalam rumusan pasal 521 Jo pasal 280 ayat 1 UU No. 7 Tahun 2017 tentang Pemilihan Umum

2. Laporan Polisi Nomor : LP/23/B/I/2019/Polres Solok Kota tgl 23 Januari 2019, tentang tindak pidana pemilu kampanye yang dilarang berupa anggota badan permusyarawatan nagari ikut serta sebagai pelaksana kampanye sebagaimana dimaksud dalam rumusan pasal 494 Jo Pasal 280 ayat (3) UU No. 7 Tahun 2017 tentang Pemilihan Umum.

3. Laporan Polisi Nomor : LP/71/B/III/2019/Polres Solok Kota tgl 8 Maret 2019, tentang tindak pidana pemilu kampanye diluar jadwal yang ditetapkan Komisi Pemilihan Umum melalui media elektronik sebagaimana dimaksud rumusan pasal 492 Jo Pasal

\footnotetext{
${ }^{1}$ Djoko Prakoso, Tindak Pidana Pemilu, CV. Rajawali, Jakarta, 1987, hlm. 148

${ }^{2}$ Edi Setiadi, sistem Peradilan Pidana Terpadu dan sistem Penegakan Hukum pidana Di Indonesia, Gramedia Pustaka Utama, Jakarta, 2017, hlm. 32
} 
276 ayat (2) Jo Pasal 275 ayat (1) Huruf f dan g UU No. 7 Tahun 2017 tentang Pemilihan Umum.

Menjelaskan data tersebut Kasat Reskrim Polres Solok Kota Iptu Defrianto, S.H., M.H. selaku Koordinator Penyidik menerangkan bahwa pelaksanaan penyidikannya perkara tindak pidana pemilu yang terjadi pada masa kampanye tergolong kualifikasi sulit, yakni kualitas modus operandi pelaku, kesulitan mendapatkan alat bukti guna memenuhi unsur pasal yang dipersangkakan terhadap orang ataupun kelompok yang diduga melakukan tindak pidana pemilu tersebut, dan dibatasi dengan prosedur khusus yang membuat penyidik harus bekerja paruh waktu semaksimal mungkin mengungkap terangnya sebuah perkara. Berdasarkan latar belakang yang dipaparkan di atas, maka permasalahan yang akan dibahas adalah Proses Penyidikan Tindak Pidana Pemilu Pada Masa Kampanye Pemilu Tahun 2019 Oleh Penyidik Satreskrim Polres Solok Kota, dan kendala yang dihadapi Penyidik Satreskrim Polres Solok Kota dalam Penyidikan Tindak Pidana Pemilu Pada Masa Kampanye Pemilu Tahun 2019.

\section{METODE PENELITIAN}

Dengan spesifikasi deskriptif analitis. Pendekatan yang digunakan adalah pendekatan Yuridis Normatif yang didukung pendekatan Yuridis Empiris. Data yang digunakan adalah data sekunder dan data primer yang dikumpulkan melalui studi kepustakaan dan wawancara. Data yang didapat dianalisis secara kualitatif dan disajikan dalam bentuk deskriptif analitis. kualitatif.

\section{PEMBAHASAN}

\section{A. Penyidikan Tindak Pidana Pemilu Pada Masa Kampanye Pemilu Tahun 2019 Oleh Satreskrim Polres Solok Kota}

Penanganan kasus tindak pidana pemilu oleh Penyidik Tindak Pidana Pemilu dari Satuan Reserse Kriminal (Satreskrim) Polres Solok Kota, secara teknis sama halnya dengan penanganan kasus pidana umum lainnya, segala administrasi penyidikan memakai petunjuk teknis penyidikan pada kepolisian dan mekanisme acara penyidikan tidak terlepas dari yang telah diatur dalam UU Nomor 8 Tahun 1981 tentang KUHAP, kemudian secara internal Kepolisian Negara Republik Indonesia dalam menjalan tugas Penyelidikan dan Penyidikan juga mempunyai Petunjuk Teknis dan Standar Operasional Prosedur melalui Peraturan Kapolri dan Peraturan Kabareskrim. Mencermati ketentuan pasal Pasal 477 UU No. 7 Tahun 2017 tentang Pemilu, yang tidak menyebutkan institusi mana yang berwenang melakukan proses penyelidikan, maka dapat dipastikan bahwa institusi yang berwenang melakukan penyelidikan tindak pidana dalam Pemilu 2019 adalah Kepolisian Negara Republik Indonesia, sesuai bunyi ketentuan Pasal 1 angka 4 UU No. 8 Tahun 1981 yang menyatakan, "Penyelidik adalah pejabat polisi negara Republik Indonesia yang diberi wewenang oleh undang-undang ini untuk melakukan penyelidikan”, dengan demikian Penyidik Tindak Pidana Pemilu yang ditugaskan dari Satreskrim Polres Solok mengemban 2 (dua) fungsi sekaligus, yakni melaksanakan penyelidikan dan penyidikan tindak pidana pemilu. Proses penanganan temuan/laporan tentang dugaan tindak pidana pemilu dan penyidikan tindak pidana pemilu adalah sebagai berikut: 
1. Dalam Pasal 19 Perbawaslu Nomor 31 Tahun 2018, Penyidik mendampingi Bawaslu dalam menerima temuan/laporan tindak pidana pemilu, dan setelah laporan diterima atau diregistrasi oleh Bawaslu maka Penyelidik mulai melaksanakan penyelidikan terhadap laporan tersebut dan wajib membuat laporan hasil penyelidikan setelah melaksanakan penyelidikan.

2. Dalam Pasal 20 Perbawaslu Nomor 31 Tahun 2018, Bawaslu bersama Penyidik dan Jaksa melaksanakan pembahasan pertama paling lama 1x24 jam terhitung sejak temuan/laporan diterima untuk menyimpulkan apakah temuan atau laporan memenuhi syarat formil dan syarat materil, dan menentukan pasal yang akan disangkakan.

3. Dalam Pasal 21 Perbawaslu Nomor 31 Tahun 2018, Berdasarkan temuan/laporan dugaan tindak pidana pemilu yang sudah diregistrasi, Penyidik dan Jaksa mendampingi Bawaslu dalam melakukan kajian terhadap temuan/laporan tersebut, kajian dilakukan paling lama 14 hari setelah temuan/laporan diregistrasi.

4. Dalam Pasal 23 Perbawaslu Nomor 31 Tahun 2018, Bawaslu bersama Penyidik dan Jaksa melaksanakan pembahasan kedua paling lama 14 hari sejak temuan/laporan diregistrasi untuk menyimpulkan temuan atau laporan merupakan tindak pidana Pemilu atau bukan tindak pidana Pemilu.

5. Dalam Pasal 24 Perbawaslu Nomor 31 Tahun 2018, paling lama 14 hari sejak temuan/laporan diregistrasi sudah dilaksanakan rapat pleno untuk memutuskan temuan atau laporan ditingkatkan ke tahap Penyidikan atau dihentikan, yang mana rapat pleno tersebut dilaksanakan berdasarkan pada hasil pembahasan kedua, kajian Pengawas Pemilu, dan laporan hasil penyelidikan dari Penyelidik. Dalam 1x24 jam setelah selesai melaksanakan rapat pleno, maka Penyidik dan Jaksa mendampingi Bawaslu membuat Laporan Polisi ke SPKT Polres setempat.

6. Dalam Pasal 25 Perbawaslu Nomor 31 Tahun 2018, Setelah terbitnya Laporan Polisi, segera menerbitkan Surat Perintah Penyidikan bersamaan dengan Surat Perintah Dimulainya Penyidikan, dan penyidikan dilaksanakan paling lama 14 (empat belas) hari terhitung sejak terbitnya Laporan Polisi. Pelaksanaan Penyidikan dilaksanakan dengan pendampingan Jaksa.

7. Dalam Pasal 26 Perbawaslu Nomor 31 Tahun 2018, pada masa penyidikan oleh unsur Kepolisian, Penyidik bersama Jaksa dan Bawaslu melaksanakan pembahasan ketiga untuk menghasilkan kesimpulan dapat atau tidaknya perkara dilimpahkan kepada Jaksa.

8. Dalam Pasal 27 Perbawaslu Nomor 31 Tahun 2018, Hasil penyidikannya disertai berkas perkara diserahkan kepada penuntut umum paling lama 14 (empat belas) hari sejak diterimanya laporan polisi dan dapat dilakukan tanpa hasil pemeriksaan tersangka. Jika hasil penyidikan belum lengkap, dalam waktu paling lama 3 (tiga) hari Penuntut Umum mengembalikan berkas perkara kepada Penyidik Polri disertai petunjuk tentang hal yang harus dilakukan untuk dilengkapi. Selanjutnya, Penyidik menyerahkan kembali berkas perkara dalam waktu paling lama 3 (tiga) hari sejak tanggal penerimaan berkas perkara.

9. Dalam Pasal 28 Perbawaslu Nomor 31 Tahun 2018, setelah berkas perkara dinyatakan lengkap oleh Jaksa, maka Penyidik segara menyerahkan tanggung jawab tersangka 
dan barang bukti kepada Penuntut Umum, dan dapat dilakukan tanpa kehadiran tersangka.

10. Selanjutnya, dalam waktu paling lama 6 (enam) hari sejak tanggal penerimaan berkas perkara, tanpa atau setelah melalui proses pengembalian berkas perkara karena penyidikan dianggap belum lengkap, Penuntut Umum pun wajib melimpahkan berkas perkara kepada Pengadilan Negeri paling lama 5 (lima)10 hari sejak menerima berkas perkara, untuk kemudian dilakukan pemeriksaan di sidang Pengadilan. Dari uraian tata cara penanganan tindak pidana dalam Pemilu 2019 berdasarkan UU No. 7 Tahun 2017 dan UU No. 8 Tahun 1981 tentang KUHAP, dapat disimpulkan bahwa penanganan tindak pidana dalam Pemilu 2019 mulai dari tahap penerusan laporan sampai pelaksanaan putusan pengadilan yang telah berkekuatan hukum tetap, melibatkan 4 (empat) institusi berbeda sesuai tahapan prosesnya yaitu Bawaslu dan/atau jajarannya sampai Panwaslu Kecamatan (penerusan laporan, 1x24 jam), Kepolisian (penyidikan, 14 hari), Kejaksaan (penuntutan, 5 sampai 11 hari), dan Pengadilan (pemeriksaan di sidang pengadilan tingkat pertama, 7 hari; dan tingkat banding, 10 hari) sampai keluarnya putusan (pengiriman dan pelaksanan putusan, 6 hari).

B. Kendala yang dihadapi Penyidik Satreskrim Polres Solok Kota dalam Penyidikan Tindak Pidana Pemilu Pada Masa Kampanye Pemilu Tahun 2019

Kendala yang dihadapi Penyidik Satreskrim Polres Solok Kota dalam melakukan Penyidikan Tindak Pidana Pemilu Pada Masa Kampanye Pemilu Tahun 2019 menjadi 2 (dua) kelompok, yaitu:

1. Kendala Eksternal (dari luar).

Terdapat kelemahan terkait dengan tata cara penanganan tindak pidana pemilu, yaitu dengan keberadaan Bawaslu yang hanya diposisikan sebagai lembaga penerus laporan/temuan dugaan tindak pidana pemilu, padahal lembaga tersebut diberi tugas menentukan dugaan tindak pidana pemilu sebagaimana diatur dalam Pasal 94 ayat (2) huruf $\mathrm{c}$ dan juga diberi kewenangan untuk meminta bahan keterangan yang dibutuhkan kepada pihak terkait dalam rangka tahapan klarifikasi tindak pidana pemilu sebagaimana diatur dalam Pasal 95 huruf g UU No. 7 Tahun 2017, sepantasnyalah bila Bawaslu dijadikan sebagai lembaga penerus laporan dugaan tindak pidana pemilu dengan segala kewenangan dimilikinya, yakni berwenang melakukan penyelidikan, penyidikan dan penuntutan tindak pidana pemilu, sama dengan lembaga independen seperti KPK (Komisi Pemberantasan Korupsi), atau Badan Narkotika Nasional, dengan demikian tidak akan ada lagi kekhawatiran sebuah laporan tindak pidana pemilu tida dapat ditindak lanjuti penanganannya hanya disebabkan salah satu dari unsur Gakkumdu (Bawaslu, Penyidik, Jaksa) tidak sepakat untuk menindaklanjuti dengan alasan normatifnya sendirisendiri, kelemahan itu dapat juga disebut sebagai kendala dalam penyidikan tindak pidana pemilu. Sentra Gakkumdu belum berfungsi efekti dalam menindaklanjuti setiap laporan atau temuan dugaan tindak pidana pemilu, karena hanya untuk menyatakan suatu perbuatan atau tindakan yang diduga sebagai tinda pidana pemilu saja Bawaslu harus satu suara dengan 2 (dua) unsur Gakkumdu yang lain yaitu Kepolisian dan Kejaksaan, padahal keberadaan Penyidik dari Kepolisian dan Jaksa dari Kejaksaan dalam Gakkumdu hanyalah sebagai forum koordinasi bagi 
Bawaslu untuk mengambil keputusan. Kenyataannya, memang tidak sedikit laporan atau temuan dugaan tindak pidana dalam Pemilu Tahun 2019 yang tidak bisa dilanjutkan ke tahap penyidikan atau harus dihentikan di tahap penyidikan dan/atau tahap penuntutan hanya karena ada salah satu unsur dalam Gakkumdu yang tidak sependapat dengan unsur Gakkumdu yang lain. Kendala lain dalam penyidikan tindak pidana pemilu tahun 2019 yaitu dibatasinya jangka waktu penanganan tindak pidana pemilu sebagaimana diatur dalam UU No. 7 Tahun 2017 tentang Pemilu, mulai dari penerusan laporan sampai pelaksanaan putusan yang telah berkekuatan hukum tetap, sedangkan aturan batasan waktu tersebut tidak diikuti dengan konsekuensi hukum apa yang akan terjadi bila penanganan tindak pidana yang dilakukan ternyata melewati jangka waktu yang telah ditentukan. Seharusnya, demi kepastian hukum sebagai salah satu asas, ketentuan pembatasan jangka waktu penanganan tindak pidana dalam UU No. 7 Tahun 2017 tentang Pemilu mestinya juga diikuti dengan ketentuan atau norma yang mengatur akibat hukumnya, misalnya bila penyidikan belum selesai dalam jangka waktu 14 (empat belas) hari, maka penyidikan harus dihentikan atau bila pemeriksaan di sidang pengadilan memakan waktu lebih dari 7 (tujuh) hari maka putusan yang dijatuhkan batal demi hukum.

Ada kendala lain sehubungan dengan pembatasan waktu penanganan tindak pidana pemilu tersebut, bahwa pembatasan waktu penanganan tindak pidana pemilu sangat menghambat Penyidik Tindak Pidana Pemilu untuk bekerja maksimal dalam mengumpulkan alat bukti, diilustrasikan kepada sebuah perkara yang saksi-saksinya berdomisili jauh dan/atau bepergian ke luar Kota dan/atau orangnya sudah diketahui sedangkan alamatnya belum ditemukan, padahal keterangan saksi tersebut merupakan kunci dari terangnya suatu perkara, sehingga perkara tersebut tidak dapat ditindak lanjuti ke tahap penuntutan dan harus dihentikan penyidikannya berdasarkan hasil rapat pembahasan ke III bersama Jaksa dan unsur Bawaslu. Selain itu, kepastian hukum penanganan tindak pidana pemilu hanya bisa dijawab secara normatif, sedangkan secara sosiologis masyarakat masih bertanya tentang profesionalisme dan transparansi penyidikan tindak pidana pemilu, rasanya sangat tidak adil jika sebuah perkara yang nyata-nyata merupakan tindak pidana harus dihentikan penyidikannya hanya karena tidak maksimalnya penyidikan mencari alat bukti disebabkan keterbatasan waktu penyidikan.

2. Kendala Internal (dari dalam)

Selain dari beberapa kendala yang disebutkan di atas, secara internal terdapat 2 (dua) kendala yang dihadapi Penyidik dalam manganani laporan pidana pemilu. Pertama, terbatasnya sarana dan prasarana selalu menjadi hambatan dan menjadi kendala dalam proses penyelidikan dan penyidikan, terutama tugas yang dilakukan oleh Penyidik, Pemerintah belum menyediakan peralatan kerja seperti perangkat komputer atau laptop yang diperuntukkan bagi Penyidik, sedangkan pelaksanaan kegiatan seperti pemeriksaan saksi-saksi dan tersangka, serta pembuatan administrasi penyidikan harus dilaksanakan di Sekretariat Bawaslu atau Posko Gakkumdu. Setelah selesainya melaksanakan kegiatan penyelidikan dan penyidikan, Penyidik juga belum difasilitasi ruang atau tempat penyimpanan dokumen dan arsipnya, sehingga pengarsipan hanya ada di Satreskrim Polres. Kedua, masih lemahnya Penyidik Tindak Pidana Pemilu 
dalam penguasaan perundang-undangan atau peraturan-peraturan berkaitan dengan Pemilu Tahun 2019, disebabkan karena pembuatan perundang-undangan atau peraturan-peraturan tersebut sangat dekat dengan waktu diberlakukannya, sedangkan Penyidik Tindak Pidana Pemilu itu sendiri hanya dibekali pelatihan selama 1 (satu) minggu, waktu pelatihan tersebut adalah waktu yang singkat untuk dapat menguasai peraturan yang baru dikenal.

\section{KESIMPULAN}

Proses Penyidikan Tindak Pidana Pemilu Pada Masa Kampanye Pemilu Tahun 2019 Oleh Penyidik Satreskrim Polres Solok Kota diawali dari kegiatan Penyidik mendampingi Bawaslu menerima temuan/laporan dugaan tindak pidana pemilu, kemudian paling lama 14 (empat belas) hari Penyidik mendampingi Bawaslu dalam melakukan klarifikasi dan kajian, setelah disimpulkan bahwa temuan/laporan tersebut adalah tindak pidana pemilu, maka laporan diteruskan kepada Polri dengan membuat Laporan Polisi, selanjutnya paling lama 14 (empat belas) hari Penyidik melaksanakan penyidikan dan paling lama 14 (empat belas) hari berkas perkara hasil penyidikan sudah diserahkan kepada Penunutut Umum.

Dalam waktu paling lama 6 (enam) hari sejak tanggal penerimaan berkas perkara, Penyidik melimpahkan tanggung jawab perkara kepada Penuntut Umum tanpa atau setelah melalui proses pengembalian berkas perkara. Kendala-kendala yang dihadapi oleh Penyidik Satreskrim Polres Solok Kota dalam Penyidikan Tindak Pidana Pemilu Pada Masa Kampanye Pemilu Tahun 2019 adalah Pertama, kendala eksternal, yaitu a) laporan tindak pidana pemilu tidak dapat ditindaklanjuti penanganannya jika salah satu dari unsur Gakkumdu (Bawaslu, Penyidik, Jaksa) tidak sepakat untuk menindaklanjuti dengan alasan normatifnya sendirisendiri; (b) dibatasinya jangka waktu penanganan tindak pidana pemilu tidak diikuti dengan konsekuensi hukum apa yang akan terjadi bila penanganan tindak pidana yang dilakukan melewati jangka waktu yang telah ditentukan; (c) pembatasan waktu penanganan tindak pidana pemilu sangat menghambat Penyidik Tindak Pidana Pemilu untuk bekerja maksimal dalam mengumpulkan alat bukti. Kedua, kendala internal, yaitu a) terbatasnya sarana dan prasarana yang dibutuhkan untuk kegiatan penyelidikan dan penyidikan; b) Masih lemahnya Penyidik Tindak Pidana Pemilu dalam penguasaan perundang-undangan atau peraturanperaturan berkaitan dengan Pemilu Tahun 2019.

\section{DAFTAR PUSTAKA}

Djoko Prakoso, Tindak Pidana Pemilu, CV. Rajawali, Jakarta, 1987.

Edi Setiadi, sistem Peradilan Pidana Terpadu dan sistem Penegakan Hukum pidana Di Indonesia, Gramedia Pustaka Utama, Jakarta, 2017

Undang-Undang Nomor 2 Tahun 2002 tentang Kepolisian Negara Republik Indonesia.

Undang-Undang Republik Indonesia Nomor 7 Tahun 2017 Tentang Pemilihan Umum.

Peraturan Badan Pengawas Pemilu Nomor 31 Tahun 2018 Tentang Sentra Penegakan Hukum Terpadu. 